Article history: Submitted 22 December 2019; Accepted 21 January 2020; Available online 1 February 2020.

\title{
Konsep Kriminalisasi Penegakan Hukum Terhadap Pembeli Aktif Ilegal Obat Keras Daftar "G" Jenis Trihexyphenidil
}

\author{
Moh. Heriyanto, Wahyu Hidayatullah, Mulyadi \\ mohammadheriyanto@yahoo.co.id \\ Universitas Airlangga
}

Keywords:
Criminalization;
Illegal active
buyers; Hard
drugs list "G"
Trihexyphenidil
type.

Kata Kunci:

Kriminalisasi;

Pembeli aktif

ilegal; Obat keras

daftar " $G$ " jenis

Trihexyphenidil.

\begin{abstract}
The hard drug list " $G$ " Trihexyphenidil type can be qualified as a dangerous drug to be misused, either in the process of production, circulation, or its use. However, the regulation in RI Law Number 36 of 2009 concerning Health only regulates penalties for illegal practices in the production and installation of its circulation, without being associated with active buyers or users. Law enforcement efforts on hard drug list "G" Trihexyphenidil type specifically for active buyers can not only discuss repressive actions only, but also must discuss prevention efforts. The concept of criminalization of illegal active buyers of the hard drug list " $G$ " Trihexyphenidil type is expected to be a manifestation of certainty and justice. This article is prepared using normative juridical research methods through the Statute Approach, Comparative Approach, and Conceptual Approach, which aims to critically positive legal regulation of law enforcement against illegal active buyers hard drugs list " $G$ " Trihexyphenidil type.
\end{abstract}

\begin{abstract}
Abstrak
Obat keras daftar "G" jenis Trihexyphenidil dapat terkualifikasi sebagai obat berbahaya apabila disalahgunakan, baik dalam proses produksi, peredaran, atau pun pemakaiannya. Namun demikian regulasi dalam UU RI Nomor 36 Tahun 2009 tentang Kesehatan hanya mengatur sanksi pidana terhadap praktik ilegal dalam tahap produksi dan tahap peredarannya saja, tanpa menyentuh terhadap pembeli aktif maupun penggunanya. Upaya penegakan hukum secara komprehensif terhadap penyalahgunaan obat keras daftar " $G$ " jenis Trihexyphenidil khususnya terhadap pembeli aktif tidak boleh hanya dipandang sebagai upaya tindakan represif semata, tetapi sekaligus harus dipandang sebagai upaya pencegahan (preventif) juga. Konsep kriminalisasi terhadap pembeli aktif ilegal obat keras daftar "G" jenis Trihexyphenidil diharapkan menjadi perwujudan penegakan hukum yang berkepastian dan berkeadilan. Artikel ini disusun dengan menggunakan metode penelitian yuridis normatif melalui Pendekatan Undang-undang, Pendekatan Perbandingan dan Pendekatan Konseptual, yang bertujuan untuk mengkaji secara kritis terhadap regulasi hukum positif penegakan hukum terhadap pembeli aktif ilegal obat keras daftar " $G$ ” jenis Trihexyphenidil.
\end{abstract}

Copyright $\odot 2020$ Universitas Airlangga

\section{Pendahuluan}

Secara tegas Pasal 1 ayat (3) Undang-Undang Dasar Negara Republik Indonesia tahun 1945 telah menyebutkan bahwa Negara Indonesia adalah negara hukum. Adapun ciri-ciri negara hukum antara lain adanya perlindungan terhadap Hak Asasi Manusia, adanya supremasi hukum, pemisahan dan pembagian 
Moh. Heriyanto, dkk: Konsep Kriminalisasi Penegakan...

kekuasaan negara, dan peradilan yang bebas. ${ }^{1}$

Kesehatan merupakan Hak Asasi Manusia, dan salah satu unsur kesejahteraan yang harus diwujudkan sesuai dengan cita-cita bangsa Indonesia sebagaimana dimaksud dalam Pancasila dan Pembukaan Undang-Undang Dasar Negara Republik Indonesia Tahun $1945 .^{2}$

Paradigma pentingnya regulasi tentang kesehatan telah dimanifestasikan secara konkrit di dalam UU RI Nomor 36 Tahun 2009 tentang Kesehatan, yang didalamnya juga mengatur tentang penegakan hukum dari sisi pidananya. Banyaknya undang-undang bersanksi pidana tampaknya telah menggeser cara pandang jika sanksi pidana yang awalnya sebagai ultimum remidium, kini telah menjadi pilihan jalan utama (premium remidium) untuk penekanan tindakan represif sekaligus upaya preventifnya.

Tidak terkecuali terhadap peredaran obat keras daftar " $G$ " jenis Trihexyphenidil juga telah diatur secara tegas di dalam undang-undang kesehatan tersebut. Sebagaimana kita ketahui bersama bahwa ketentuan pidana dalam undang-undang kesehatan tersebut diatur pada Bab XX mulai pasal 190 sampai pasal 201 (12 pasal). Namun demikian sanksi pidana tersebut yaitu peredaran obat keras daftar "G" Trihexyphenidil secara ilegal baru menyentuh tahap produksi dan tahap peredarannya saja, tanpa menyentuh terhadap pembeli aktif atau yang memiliki, menyimpan serta menguasai maupun menggunakannya.

Hal ini berbeda dengan undang-undang No. 35 tahun 2009 Tentang Narkotika yang telah mengatur secara lebih komprehensif tentang sanksi pidana terhadap peredaran ilegal narkotika baik dari sisi penjual/pengedar, pembeli, penyimpan, bahkan penyalahgunanya, dalam undang-undang narkotika tersebut ketentuan pidananya diatur pada Bab XV mulai pasal 111 sampai dengan pasal 148 (38 pasal). Ketentuan pidana pada undang-undang narkotika tersebut lebih banyak daripada undang-undang kesehatan.

1 Dede Rosyada, Pendidikan Kewarganegaraan Demokrasi, HAM, Dan Masyarakat Madani (Puslit IAIN Syarif Hidayatullah 2000).[184].

2 Penjelasan Umum UU RI Nomor 36 Tahun 2009 tentang Kesehatan. 
Obat keras daftar "G" jenis Trihexyphenidil dengan narkotika samasama dapat digunakan sebagai obat bagi seorang yang sakit tentunya dibawah pengawasan dokter dan sebaliknya akan menjadi racun apabila digunakan tanpa pengasan ahlinya / dokter. Meskipun terdapat kesamaan sebagaimana tersebut akan tetapi terdapat perbedaan bagi yang melanggar kedua undang-undang tersebut. Apakah obat keras daftar " $G$ " jenis Trihexyphenidil tidak seberbahaya narkotika, namun demikian penyalahgunaan secara ilegal obat keras daftar " $G$ " jenis Trihexyphenidil cenderung semakin banyak, dengan pelaku rata-rata dari kalangan menengah ke bawah karena memang harganya relatif lebih murah.

Sanksi pidana dalam undang-undang kesehatan yang hanya terbatas pada produsen dan pengedar ilegal obat keras daftar " $G$ " jenis Trihexyphenidil dinilai masih kurang lengkap, sebab pada dasarnya masih ada pembeli aktif ilegal yang turut mempengaruhi terjadinya peredaran obat keras daftar " $G$ " jenis Trihexyphenidil tersebut. Pembeli aktif disini harus diartikan sebagai pembeli yang memang memenuhi unsur "dengan sengaja" yang memiliki kualifikasi "wellen en wetten" yaitu menghendaki dan mengetahui, sehingga tidak diaturnya sanksi pidana bagi pembeli aktif ilegal obat keras daftar " $G$ " jenis Trihexyphenidil di dalam UU RI Nomor 36 Rahun 2009 tentang Kesehatan, dipandang sebagai penegakan hukum yang kurang maksimal, bahkan kurang berkepastian hukum dan kurang berkeadilan.

Telah diketahui bahwa dalam proses penegakan hukum, ada tiga hal tujuan yang harus diperhatikan, yaitu kepastian hukum, kemanfaatan dan keadilan. ${ }^{3}$ Tujuan hukum berupa keadilan memang menjadi isu sensitif yang sangat sering dibicarakan dalam penegakan hukum. M Yahya Harahap mengemukakan jika menegakkan hukum dan keadilan adalah mustahil. Terutama menyangkut dengan keadilan itu sendiri, karena keadilan adalah sesuatu nilai dan rasa yang bersifat nisbi atau relatif, apa yang dianggap adil bagi seseorang atau suatu kelompok, belum tentu dirasakan adil bagi orang lain atau kelompok tertentu, seolah-olah

\footnotetext{
3 Sudikno Mertokusumo, Mengenal Hukum (Liberty 1986).[130].
} 
Moh. Heriyanto, dkk: Konsep Kriminalisasi Penegakan...

nilai dan rasa keadilan terbatas untuk suatu kelompok dalam suatu batas ruang dan waktu tertentu (for a particular people and particular time and place). ${ }^{4}$

Selain itu juga telah dikenal sistem hukum pidana Indonesia terkait asas nullum delictum nulla poena sine praevia lege poenali, yang artinya tidak ada delik, tidak ada pidana tanpa peraturan terlebih dahulu. ${ }^{5}$ Berdasarkan asas tersebut dapat dikatakan bahwa tidak ada perbuatan yang dilarang dan diancam dengan pidana jika tidak ditentukan terlebih dahulu dalam peraturan perundangundangan. Suatu perbuatan yang merupakan perbuatan pidana akan diselesaikan melalui proses persidangan menggunakan tata cara yang dianut dalam hukum acara pidana.

Lebih lanjut Moeljatno menyatakan bahwa perbuatan yang oleh hukum pidana dilarang dan diancam dengan pidana dinamakan perbuatan pidana. ${ }^{6}$ Berdasarkan hal ini maka setiap orang yang melakukan perbuatan pidana akan dikenai sanksi berupa penjatuhan pidana tertentu seperti yang diatur dan diancamkan dalam setiap rumusan delik di dalam KUHP maupun peraturan perundang-undangan khusus di luar KUHP seperti dalam undang-undang kesehatan tersebut.

Bisa dipastikan apabila di dalam UU RI Nomor 36 Rahun 2009 tentang Kesehatan tidak mengatur tentang sanksi pidana terhadap pembeli aktif obat keras daftar "G" jenis Trihexyphenidil tanpa izin maka hal tersebut tentu saja tidak dapat dipidana. Hal inilah yang membuat perlu adanya formulasi hukum khusus sebagai politik hukum pidana kedepan tentang konsep kriminalisasi terhadap pembeli aktif ilegal obat keras daftar " $G$ " secara umum, yang di dalamnya terlingkup ketentuan pidana tentang obat keras daftar " $G$ " jenis Trihexyphenidil

Kriminalisasi disini tidak boleh diartikan secara sempit, namun harus dipahami secara pengertian normatif bahwa kriminalisasi adalah proses penetapan suatu perbuatan seseorang sebagai perbuatan yang dapat dipidana. Proses ini

${ }^{4}$ M Yahya Harahap, Pembahasan Permasalahan Dan Penerapan KUHAP Pemeriksaan Sidang Pengadilan, Banding, Kasasi, Dan Peninjauan Kembali (Sinar Grafika 2008).[65].

${ }_{6}$ Moeljatno, Asas Asas Hukum Pidana (Rineka Cipta 2002).[23].

6 ibid.[2]. 
diakhiri dengan terbentuknya undang-undang dimana perbuatan itu diancam dengan sanksi yang berupa pidana. ${ }^{7}$ Beberapa persoalan inilah yang membuat penulis tertarik untuk mengkaji lebih lanjut tentang Konsep Kriminalisasi Penegakan Hukum Terhadap Pembeli Aktif Ilegal Obat Keras Daftar "G" jenis Trihexyphenidil.

\section{Metode Penelitian}

Metode penelitian yang digunakan dalam tulisan ini menggunakan tipe penelitian yuridis normatif, dengan pendekatan masalah yang digunakan melalui pendekatan undang-undang (statute approach), pendekatan perbandingan (comparative approach), dan pendekatan konseptual (conceptual approach). ${ }^{8}$ Adapun sumber bahan hukum yang dipakai adalah sumber bahan hukum primair berupa peraturan perundang-undangan terkait, bahan hukum sekunder berupa buku-buku tentang hukum, dan bahan non hukum berupa buku-buku diluar hukum. ${ }^{9}$ Terkait dengan metode analisis bahan hukum yang digunakan dalam tulisan ini menggunakan metode deduktif, yaitu berpangkal dari prinsipprinsip dasar kemudian menghadirkan objek yang hendak diteliti, dengan kata lain, berpangkal dari prinsip-prinsip umum menuju prinsip-prinsip khusus. ${ }^{10}$

Permasalahan Regulasi Sanksi Pidana Terhadap Pembeli, Penyimpan, Pemilik dan/atau pengguna Obat Keras (Daftar "G" Jenis Trihexyphenidil) Dalam UU RI Nomor 36 Tahun 2009 Tentang Kesehatan.

Sanksi pidana merupakan penderitaan atau nestapa yang dibebankan kepada orang yang melakukan perbuatan yang memenuhi unsur syarat-syarat tertentu. ${ }^{11}$ Lebih lanjut Roslan Saleh menegaskan jika sanksi pidana merupakan reaksi atas

7 Sudarto, Kapita Selekta Hukum Pidana (Alumni 1986).[31].

8 Peter Mahmud Marzuki, Penelitian Hukum (Kencana Prenada Media Group 2008).hlm. 93.

9 ibid.[141-143].

10 ibid.[42]. 2009).[8].

${ }^{11}$ Tri Andarisman, Asas-Asas Dan Dasar Aturan Hukum Pidana Indonesia (Unila Bandar Lampung 
Moh. Heriyanto, dkk: Konsep Kriminalisasi Penegakan...

delik, dan ini berwujud suatu nestapa yang dengan sengaja dilimpahkan kepada negara kepada pembuat delik. ${ }^{12}$

Norma-norma atau kaidah-kaidah dalam bidang hukum tata negara dan hukum tata usaha negara harus pertama-tama ditanggapi dengan sanksi administrasi, begitu pula norma-norma dalam bidang hukum perdata pertamatama harus ditanggapi dengan sanksi perdata. Hanya, apabila sanksi administrasi dan sanksi perdata ini belum mencukupi untuk mencapai tujuan meluruskan neraca kemasyarakatan, maka baru diadakan juga sanksi pidana sebagai pamungkas (terakhir) atau ultimum remedium. ${ }^{13}$ Sifat sanksi pidana sebagai senjata pamungkas atau ultimum remedium jika dibandingkan dengan sanksi perdata atau sanksi administrasi sudah menimbulkan kecenderungan untuk menghemat dalam mengadakan sanksi pidana. Jadi, dari sini kita ketahui bahwa ultimum remedium merupakan istilah yang menggambarkan suatu sifat sanksi pidana. ${ }^{14}$

Telah diketahui jika saat ini telah terjadi pergeseran cara pandang tentang sanksi pidana sebagai jalan terakhir (ultimum remidium), menjadi sanksi pidana sebagai senjata utama (premium remidium). Hal ini disebut-sebut sebagai manifestasi teori hukum pidana modern untuk menanggulangi kejahatan. Jadi selain sanksi pidana digunakan sebagai tindakan penindakan sekaligus juga sebagai upaya pencegahan.

Adanya beberapa ketentuan sanksi pidana yang relatif berat sampai pada batas maksimal 15 (lima belas) tahun dalam sebuah undang-undang administrasi bersanksi pidana telah menunjukkan jika pada dasarnya UU RI Nomor 36 Tahun 2009 tentang Kesehatan juga telah memberlakukan sanksi pidana sebagai premium remidium di dalamnya.

Adapun salah satu perbuatan yang mempunyai sanksi pidana berkaitan dengan peredaran Obat Keras Daftar " $G$ " jenis Trihexyphenidil diatur dalam Pasal 196 UU RI Nomor 36 Tahun 2009 tentang Kesehatan. Walaupun dalam unsur

\footnotetext{
${ }^{12}$ Roslan Saleh, Pelajaran Hukum Pidana I (Raja Grafindo Persada 2011).[81].

${ }^{13}$ Wirjono Prodjodikoro, Asas-Asas Hukum Pidana Di Indonesia (Refika Aditama 2016).[17].

14 ibid.[50].
} 
delik pasal yang dimaksud tidak spesifik menyebutkan tentang Obat Keras Daftar "G" jenis Trihexyphenidil, namun hal tersebut dapat ditemukan dalam peraturan turunannya, serta kasuistis terhadap pemeriksaan barang bukti pil yang tertuang dalam surat hasil pemeriksaan laboratoris kriminalistik Polri.

\section{UU RI Nomor 36 Tahun 2009 tentang Kesehatan}

Setiap orang yang dengan sengaja memproduksi atau mengedarkan sediaan farmasi dan/atau alat kesehatan yang tidak memenuhi standar dan/atau persyaratan keamanan, khasiat atau kemanfaatan, dan mutu sebagaimana dimaksud dalam Pasal 98 ayat (2) dan ayat (3) dipidana dengan pidana penjara paling lama 10 (sepuluh) tahun dan denda paling banyak Rp.1.000.000.000-, (satu miliar rupiah).

Pasal 98 ayat (2)

Setiap orang yang tidak memiliki keahlian dan kewenangan dilarang mengadakan, menyimpan, mengolah, mempromosikan, dan mengedarkan obat dan bahan yang berkhasiat obat.

Pasal 98 ayat (3) Ketentuan mengenai pengadaan, penyimpanan, pengolahan, promosi, pengedaran sediaan farmasi dan alat kesehatan harus memenuhi standar mutu pelayanan farmasi yang ditetapkan dengan Peraturan Pemerintah.

Pengertian sediaan farmasi sebagaimana dalam ketentuan Pasal 196 UU RI Nomor 36 Tahun 2009 tentang Kesehatan di atas adalah obat, bahan obat, obat tradisional dan kosmetika. ${ }^{15}$ Obat jenis Trihexyphenidil merupakan obat yang termasuk dalam obat daftar "G". Huruf "G" berasal dari kata Gevarijk yang artinya berbahaya. Kelompok " $G$ " meliputi obat keras yang hanya dapat dibeli dengan menggunakan resep dokter. ${ }^{16}$

Sebagaimana dalam tabel diatas, bahwa ketentuan pidana dalam pasal 196 tersebut mengacu pada pasal 98 ayat (2) dan ayat (3). Pada ayat 2 tersebut menyebutkan bahwa "Setiap orang yang tidak memiliki keahlian dan kewenangan dilarang mengadakan, menyimpan, mengolah, mempromosikan, dan mengedarkan obat dan bahan yang berkhasiat obat". Sedangkan dalam pasal 196 berbunyi "Setiap orang yang dengan sengaja memproduksi atau mengedarkan sediaan farmasi dan/atau alat kesehatan yang tidak memenuhi standar dan/atau persyaratan keamanan, khasiat atau

\footnotetext{
15 Vide Pasal 1 angka 4 Undang-undang Nomor 36 tahun 2009 tentang kesehatan

${ }^{16}$ Farmasi.com, 'Obat - Obat Daftar G' (artikelfarmasi.com, 2017) < http:/ / www.artikelfarmasi. com/2017/05/obat-obat-daftar-g.html> accessed 18 February 2019.
} 
Moh. Heriyanto, dkk: Konsep Kriminalisasi Penegakan...

kemanfaatan, dan mutu sebagaimana dimaksud dalam Pasal 98 ayat (2) dan ayat (3) dipidana dengan pidana penjara paling lama 10 (sepuluh) tahun dan denda paling banyak Rp.1.000.000.000-, (satu miliar rupiah)". Dalam ketentuan pidana ini sama sekali tidak menyinggung sanksi/pidana bagi orang yang "menyimpannya" saja dan/ atau dengan maksud untuk disalahgunakannya / dikonsumsinya.

Kami penulis belum pernah menemukan adanya raktek peradilan terkait dengan sanksi yang diberikan kepada orang yang memiliki, menyimpan dan atau menguasai obat keras jenis Trihexyphenidil. Untuk membuktikan bahwa seseorang telah dengan sengaja memproduksi atau mengedarkan sediaan farmasi dan/ atau alat kesehatan tentunya harus ada pembelinya atau orang yang menerima sediaan farmasi dan/atau alat kesehatan tersebut.

Obat keras seperti daftar " $G$ " jenis Trihexyphenidil dengan narkotika sama-sama merupakan bahan obat yang dapat dijadikan sebagai obat bagi orang yang sakit tentunya dibawah pengawasan dokter atau digunakan sebagai pengembangan ilmu pengetahuan kemudian apabila kita bandingkan antara undang-undang kesehatan dengan undang-undang narkotika maka dapat kita ketahui bahwa untuk sanksi yang ada pada undang-undang narkotika lebih lengkap mulai dari peredaran ilegal narkotika baik dari sisi penjual/pengedar, pembeli, penyimpan, bahkan penyalahgunanya sedangkan saknsi yang ada pada undang-undang kesehatan lebih menekankan kepada peredaran ilegalnya saja, sehingga tidak jarang praktek dilapangan penyidik/polri kebingungan terhadap tindakan hukum apa ketika melakukan penangkapan terhadap seorang pengedar obat keras (seperti daftar "G" jenis Trihexyphenidil) saja tanpa menangkap pembeli / penerima sehingga tidak jarang hanya diberikan teguran lisa saja sementara disisi lain terdapat bahaya yang mengancam jiwa bagi yang menyalahgunakan obat keras seperti daftar " $G$ " jenis Trihexyphenidil tersebut.

Apabila dilihat per-kasuistis terhadap pemeriksaan barang bukti pil yang tertuang dalam surat hasil pemeriksaan laboratoris kriminalistik Polri dapat diketahui jika barang bukti pil yang di dalamnya terkandung positif Trihexyphenidil adalah mempunyai efek anti parkinson, tidak termasuk narkotika 
maupun psikotropika, tetapi termasuk dalam daftar obat keras. ${ }^{17}$

Obat keras adalah obat-obat yang hanya dapat dibeli di apotek dengan resep dokter, dan boleh diulang tanpa resep dokter apabila dokter menyatakan "boleh diulang". Disebut obat keras jika pemakai tidak memperhatikan dosis, aturan pakai, dan peringatan yang diberikan, dapat menimbulkan efek berbahaya, dan hanya bisa diperoleh di apotek, dalam kemasannya ditandai dengan lingkaran merah dengan huruf " $\mathrm{K}$ " ditengahnya. ${ }^{18}$

Ketentuan Pasal 196 UU RI Nomor 36 Tahun 2009 Tentang Kesehatan telah melegitimasi bahwa pada hakikatnya Obat Keras Daftar " $G$ " jenis Trihexyphenidil tidak dilarang peredarannya asalkan memenuhi syarat-syarat yang telah ditentukan. Hal ini berbeda dengan ketentuan obat bebas terbatas seperti contoh obat Dextromethorpan sebagaimana diatur dalam Pasal 197 UU RI Nomor 36 Tahun 2009 Tentang Kesehatan, yang dilarang dalam hal ini memang peredaran obatnya.

\section{UU RI Nomor 36 Tahun 2009 tentang Kesehatan}

Setiap orang yang dengan sengaja memproduksi atau mengedarkan sediaan farmasi dan/atau alat kesehatan yang tidak memiliki izin edar

Pasal 197 sebagaimana dimaksud dalam Pasal 106 ayat (1) dipidana dengan pidana penjara paling lama 15 (lima belas) tahun dan denda paling banyak Rp.1.500.000.000,00 (satu miliar lima ratus juta rupiah).

Pasal 106 ayat (1)

Sediaan farmasi dan alat kesehatan hanya dapat diedarkan setelah mendapat izin edar.

Apabila kita cermati uraian di atas maka proses pembelian obat keras tidak terkecuali Obat Keras Daftar " $G$ " jenis Trihexyphenidil harus dilakukan dengan resep dokter, jadi apabila ada pembeli yang tidak mempunyai resep dokter kemudian membeli obat keras tidak terkecuali Obat Keras Daftar " $G$ " jenis Trihexyphenidil, maka pada hakikatnya pembeli tersebut sebenarnya telah melanggar klausul ketentuan tentang peredaran obat keras. Namun demikian

17 Adapun narasi hasil pemeriksaan laboratoris kriminalistik Polri terhadap pemeriksaan barang bukti pil yang di dalamnya terkandung positif Trihexyphenidil adalah relatif hampir sama, namun demikian untuk memberikan kepastian rujukan terhadap tulisan di atas maka penulis menggunakan Berita Acara Pemeriksaan Laboratoris Kriminalistik No.Lab: 9144/NOF/2018 tertanggal 05 Oktober 2018 pada Badan Reserse Kriminal Polri Pusat Laboratorium Forensik Cabang Surabaya.

18 Vide Permenkes RI Nomor 949/Menkes/Per/VI/2000. 
Moh. Heriyanto, dkk: Konsep Kriminalisasi Penegakan...

sanksi pidana terkait peredaran obat keras daftar " $G$ " Trihexyphenidil secara ilegal baru menyentuh pada tahap produksi dan tahap peredarannya saja, tanpa menyentuh terhadap pembeli aktif maupun penggunanya, terseirat bahwa seseorang yang membeli obat keras dengan maksud untuk digunakan maka orang tersebut sempat memiliki, menyimpan atau menguasai obat keras tersebut.

Hal ini tentunya berbeda dengan undang-undang narkotika yang telah mengatur secara lebih komprehensif tentang sanksi pidana terhadap peredaran ilegal narkotika baik dari sisi penjual/pengedar, pembeli, penyimpan, bahkan penggunanya.

\section{UU RI Nomor 35 Tahun 2009 tentang Narkotika}

Setiap orang yang tanpa hak atau melawan hukummenanam, memelihara, memiliki, menyimpan, menguasai, atau menyediakan Narkotika

Pasal 111 ayat (1) Golongan I dalam bentuk tanaman, dipidana dengan pidana penjara paling singkat 4 (empat) tahun dan paling lama 12 (dua belas) tahun dan pidana denda paling sedikit Rp800.000.000-, (delapan ratus juta rupiah) dan paling banyak Rp8.000.000.000-, (delapan miliar rupiah).

Setiap orang yang tanpa hak atau melawan hukum memiliki, menyimpan, menguasai, atau menyediakan Narkotika Golongan I bukan Pasal 112 ayat (1) tanaman, dipidana dengan pidana penjara paling singkat 4 (empat) tahun dan paling lama 12 (dua belas) tahun dan pidana denda paling sedikit Rp.800.000.000-, (delapan ratus juta rupiah) dan paling banyak Rp.8.000.000.000-, (delapan miliar rupiah).

Setiap orang yang tanpa hak atau melawan hukum menawarkan untuk dijual, menjual, membeli, menerima, menjadi perantara dalam jual beli, menukar, atau menyerahkan Narkotika Golongan I, dipidana dengan

Pasal 114 ayat (1) pidana penjara seumur hidup atau pidana penjara paling singkat 5 (lima) tahun dan paling lama 20 (dua puluh) tahun dan pidana denda paling sedikit Rp.1.000.000.000-, (satu miliar rupiah) dan paling banyak Rp.10.000.000.000-, (sepuluh miliar rupiah).

Setiap Penyalah Guna:

a. Narkotika Golongan I bagi diri sendiri dipidana dengan pidana penjara paling lama 4 (empat) tahun;

Pasal 127 ayat (1)

b. Narkotika Golongan II bagi diri sendiri dipidana dengan pidana penjara paling lama 2 (dua) tahun; dan

c. Narkotika Golongan III bagi diri sendiri dipidana dengan pidana penjara paling lama 1 (satu) tahun.

Secara faktual obat keras bisa dikatakan tidak seberbahaya narkotika. Namun demikian tidak diaturnya pembeli aktif ilegal dalam ketentuan sanksi pidana membuat potensi penegakan hukum dalam tahap pemberantasan peredaran Obat Keras Daftar " $G$ " jenis Trihexyphenidil menjadi tidak maksimal. 
Karena pada hakikatnya ketika pembeli telah membeli Obat Keras Daftar "G" jenis Trihexyphenidil tanpa menggunakan resep dokter, maka pembeli tersebut tentunya telah memenuhi unsur "dengan sengaja", yang artinya pembeli telah meniati sesuai dengan kehendaknya atau dalam keadaan dengan mengetahui dan menghendaki (willen en wetten). Hal inilah yang disebut penulis dengan sebutan pembeli aktif ilegal Obat Keras Daftar "G" jenis Trihexyphenidil.

Selain itu keadaan lain yang berpeluang terjadi adalah adanya potensi jebak menjebak dalam proses penegakan hukum pemberantasan Obat Keras Daftar "G" jenis Trihexyphenidil, oleh karena yang bisa dipidana hanyalah penjual/pengedar ilegal saja, tetapi tidak berlaku untuk pembeli aktif ilegal Obat Keras Daftar "G" jenis Trihexyphenidil.

Konsep Kriminalisasi Penegakan Hukum Terhadap Pembeli, Penyimpan, Pemilik dan/atau pengguna Ilegal Obat Keras Daftar "G" Trihexyphenidil Sebagai Ius Constituendum.

Penegakan hukum merupakan suatu usaha untuk mewujudkan ide-ide tentang kepastian hukum, kemanfaatan sosial dan keadilan menjadi kenyataan. Proses perwujudan ide-ide itulah yang merupakan hakikat dari penegakan hukum. ${ }^{19}$ Penegakan hukum adalah sebuah tugas. Tugas yang diemban oleh aparat penegak hukum, dan karena tugas, seperti dikatakan Kant, merupakan "kewajiban kategoris", "kewajiban mutlak". Disini tidak mengenal istilah "dengan syarat". Tugas adalah tugas, wajib dilaksanakan. ${ }^{20}$

Merujuk pada uraian sebelumnya maka sudah selayaknya terminologi pembeli aktif ilegal Obat Keras (seperti daftar " $G$ " jenis Trihexyphenidil) secara hukum diresmikan dengan menjadikannya sebagai delik tersendiri dalam undangundang kesehatan, baik sebagai delik yang memang benar-benar baru atau pun berupa klausul lanjutan dari delik sebelumnya, sehingga nantinya kualifikasi pembeli aktif ilegal Obat Keras Daftar " $G$ " jenis Trihexyphenidil benar-benar telah

\footnotetext{
19 Satjipto Raharjo, Masalah Penegakan Hukum Suatu Tinjauan Sosiologis (Sinar Baru 2005).[24].

${ }^{20}$ Bernard L Tanya, Penegakan Hukum Dalam Terang Etika (Genta Publising 2001).[35].
} 
Moh. Heriyanto, dkk: Konsep Kriminalisasi Penegakan...

teradopsi menjadi tindakan yang menurut sesuatu rumusan undang-undang telah dinyatakan sebagai tindakan khusus yang dapat dihukum.

Menjadi relevan apabila hal tersebut juga untuk memenuhi asas "nullum delictum nulla poena sine praevia lege poenali", yang artinya tidak ada delik, tidak ada pidana tanpa peraturan terlebih dahulu" ${ }^{21}$ Berdasarkan asas tersebut dapat dikatakan bahwa tidak ada perbuatan yang dilarang dan diancam dengan pidana jika tidak ditentukan terlebih dahulu dalam peraturan perundang-undangan.

Upaya penegakan hukum terhadap peredaran Obat Keras Daftar " $G$ " jenis Trihexyphenidil harus dilakukan secara komprehensif dimulai dari hulu sampai hilir dalam sebuah teori sistem hukum sebagaimana dikemukakan oleh Lawrence M. Friedmen ${ }^{22}$ yang membagi sistem hukum menjadi tiga bagian yaitu: substansi hukum (legal substance), struktur hukum (legal structure), dan budaya hukum (legal culture).

Subtansi hukum (legal substance) bisa dikatakan sebagai norma, aturan, dan perilaku nyata manusia yang berada pada sistem itu. Pemberantasan peredaran Obat Keras Daftar " $G$ " jenis Trihexyphenidil harus sudah dibangun sejak peraturan perundang-undangan tersebut diformulasikan. Para pembuat peraturan perundang-undangan sejatinya jangan hanya terpaku pada norma hukum apa yang hendak dilarang atau dianjurkan, tetapi harus berpikir lebih jauh lagi sampai ke batas akibat apa yang dapat ditimbulkan dari substansi larangan atau pun anjuran norma hukum tersebut.

Sebuah ajaran Teori Relevansi yang dianut oleh Langemeyer dapat diaplikasikan dalam tahapan ini. Menurut Moeljatno, pokok dalam teori relevansi yaitu pada waktu undang-undang menentukan rumusan delik, kelakuankelakuan yang manakah yang dibayangkan olehnya dapat menimbulkan akibat yang dilarang. Teori relevansi bukanlah lagi suatu teori mengenai hubungan kausal, tetapi lebih mengenai penafsiran undang-undang, suatu teori mengenai interpretasi. Kelakuan yang relevan tadi harus menjadi conditio sine qua non dalam

\footnotetext{
${ }^{21}$ Moeljatno (n 5).Op Cit.[20].

${ }^{22}$ Lawrence M. Friedman, Sistem Hukum: Perspektif Ilmu Sosial (The Legal System: A Social Science Perspective (Nusa Media 2009).[33].
} 
proses timbulnya akibat. ${ }^{23}$

Berdasarkan uraian di atas, maka sebuah norma hukum yang dihasilkan akan jauh berkualitas karena dapat menjangkau sampai pada akibat selanjutnya dari pengaturan norma hukum tersebut. Norma hukum yang demikian tentunya dapat menjadi pijakan yang jelas dan tegas bagi komponen sistem hukum berikutnya yaitu struktur hukum (legal structure) dalam melaksanakan tugas penegakan hukumnya.

Struktur hukum (legal structure), bisa dikatakan sebagai kerangka bentuk yang permanen dari sistem hukum yang menjaga proses tetap berada di dalam batas-batasnya, yang menentukan bisa atau tidaknya hukum itu dilaksanakan dengan baik. Wujud konkrit dari struktur hukum (legal structure) yang dengan mudah dapat kita lihat adalah 4 (empat) komponen dalam sistem peradilan pidana terpadu (integrated criminal justice system) terdiri atas Kepolisian, Kejaksaan, Pengadilan, dan Pemasyarakatan, yang lebih spesifik secara personal terdiri dari Polisi, Jaksa, Hakim, dan Petugas Pemasyarakatan. Wadah sistem peradilan pidana terpadu inilah yang memperlihatkan wujud interkoneksi antar personal dan lembaga penegak hukum pidana, sehingga diharapkan terangkai criminal justice process ${ }^{24}$ yang memenuhi rasa keadilan dalam masyarakat. ${ }^{25}$

Secara umum tata laksana para legal structure sudah termuat dalam ranah Hukum Acara. Meskipun dalam Hukum Acara dalam pelaksanaannya telah dilengkapi dengan berbagai peraturan yang berfungsi sebagai petunjuk lebih lanjut untuk penerapannya dalam praktik hukum, meski kenyataannya masih juga terjadi adanya sikap dan tingkah laku serta tindakan para pejabat atau petugas penegak hukum yang tidak sesuai bahkan bertentangan dengan jiwa dan semangat yang terkandung dalam Hukum Acara tersebut. ${ }^{26}$

23 Moeljatno (n 5)., Op.Cit.[113].

${ }^{24}$ Criminal justice process adalah setiap tahap dari suatu putusan yang menghadapkan seorang tersangka ke dalam proses yang membawanya kepada ketentuan pidana baginya.

${ }^{25}$ Y\&Adang Anwar, Sistem Peradilan Pidana: Konsep, Komponen, E Pelaksanaannya Dalam Penegakan Hukum Di Indonesia (Widya Padjajaran 2011).[36].

${ }^{26}$ H.M.A. Kuffal, Penerapan Kuhap dalam Praktik Hukum, UPT Penerbitan Universitas Muhammadiyah Malang, Malang, 2005, hlm. 7. Tanpa bermaksud mengubah makna namun hanya sebatas sebagai perluasan makna, maka penulisan kata-kata KUHAP dalam tulisan H.M.A. Kuffal tersebut oleh penulis diganti dengan kata-kata Hukum Acara.. 
Moh. Heriyanto, dkk: Konsep Kriminalisasi Penegakan...

Apabila nantinya pembeli, Penyimpan, Pemilik dan/atau pengguna ilegal Obat Keras Daftar "G" jenis Trihexyphenidil telah menjadi suatu delik khusus dalam undang-undang kesehatan, maka dapat dijadikan pijakan sebagai dasar hukum yang kuat bagi para aparat penegak hukum untuk bertindak secara preventif atau pun represif. Hasil kerja dari struktur hukum yang berdasarkan atas substansi hukum inilah yang nantinya diharapkan membentuk pola pikir (mindset) dan pola tindak masyarakat yang lebih komprehensif dengan menerapkan anti penggunaan obat keras sebagai budaya hukum.

Budaya hukum merupakan keseluruhan sikap dari masyarakat, juga sebagai sistem nilai yang ada dalam masyarakat yang akan menentukan bagaimana seharusnya hukum itu berlaku dalam masyarakat yang bersangkutan. Budaya Hukum dapat dikatakan sebagai buah kerja dari substansi hukum dan struktur hukum. Jadi masyarakat akan menjadi sadar hukum dengan sendirinya. Budaya hukum masyarakat inilah nantinya sebagai titik masuk (entry point) untuk memerangi peredaran Obat Keras Daftar " $G$ " jenis Trihexyphenidil dalam jangka panjang. Sesuatu hal yang dapat dipandang sebagai sesuatu yang lebih progresif dan humanis karena tidak sekedar menakut-nakuti dengan ancaman pasal perpasal. Masyarakat yang sudah sadar hukum akan bahaya Obat Keras Daftar "G" jenis Trihexyphenidil diharapkan akan menularkan kepada masyarakat lain seperti layaknya efek domino.

Hukum positif yang ada dalam UU RI Nomor 36 Tahun 2009 tentang Kesehatan memang tidak mengatur tentang pembeli aktif ilegal Obat Keras Daftar " $G$ " jenis Trihexyphenidil, sehingga penegak hukum tidak bisa menjeratnya. Atas hal tersebut diperlukan upaya kriminalisasi. Kriminalisasi disini tidak boleh diartikan secara sempit, namun harus dipahami secara normatif bahwa kriminalisasi adalah proses penetapan suatu perbuatan seseorang sebagai perbuatan yang dapat dipidana. Proses ini diakhiri dengan terbentuknya undangundang dimana perbuatan itu diancam dengan sanksi yang berupa pidana.

Adapun ukuran yang secara doktrinal harus diperhatikan sebagai pedoman dalam kriminalisasi tersebut yaitu: 
1. Kriminalisasi tidak boleh terkesan menimbulkan over kriminalisasi yang masuk kategori the missue of criminal sanction;

2. Kriminalisasi tidak boleh bersifat ad hoc;

3. Kriminalisasi harus mengandung unsur korban victimizing baik aktual maupun potensial;

4. Kriminalisasi harus memperhitungkan analisa biaya dan hasil dan prinsip ultimum remidium;

5. Kriminalisasi harus menghasilkan peraturan yang enforcable;

6. Kriminalisasi harus mampu memperoleh dukungan publik;

7. Kriminalisasi harus mengandung unsur subsosialitet mengakibatkan bahaya bagi masyarakat sekalipun kecil sekali;

8. Kriminalisasi harus memperhatikan peringatan bahwa setiap peraturan pidana membatasi kebebasan rakyat dan memberikan kemungkinan kepada aparat penegak hukum untuk mengekang kebebasan itu. ${ }^{27}$.

Konsep kriminalisasi pembeli, Penyimpan, Pemilik dan/atau pengguna ilegal Obat Keras (seperti daftar "G" jenis Trihexyphenidil) saat ini menjadi menarik untuk didiskusikan. Para pelaku yang terjerat pidana berupa penjual atau pengedar, yang menjual Obat Keras Daftar "G" jenis Trihexyphenidil kepada pembeli yang jelas-jelas telah dengan sengaja membeli Obat Keras Daftar "G" jenis Trihexyphenidil tanpa ada resep dokter cenderung tidak mendapatkan keadilan, karena hubungan kausalitas antara penjual dan pembeli tidak dapat dipisahkan, dan pembeli aktif ilegal Obat Keras Daftar "G" jenis Trihexyphenidil dinilai telah memenuhi unsur "dengan sengaja" yang memiliki kualifikasi "wellen en wetten" yaitu menghendaki dan mengetahui, membuat equalitity before the law tidak dapat terwujudkan.

Hal ini dapat dimaklumi karena belum ada pengaturan secara resmi tentang pembeli aktif ilegal Obat Keras Daftar " $G$ " jenis Trihexyphenidil. Memperhatikan ketentuan UU RI Nomor 12 Tahun 2011 tentang Pembentukan Peraturan Perundang-undangan, serta peraturan perundang-undangan lain yang berkaitan, sudah saatnya pembeli aktif ilegal Obat Keras Daftar " $G$ " jenis Trihexyphenidil dijadikan delik khusus dalam lingkup undang-undang kesehatan.

${ }^{27}$ Muladi, Kapita Selekta Hukum Pidana (Badan Penerbit Universitas Diponegoro 1995).[256]. 
Moh. Heriyanto, dkk: Konsep Kriminalisasi Penegakan...

\section{Kesimpulan}

Tidak diaturnya pembeli, penyimpan, pemilik dan/atau pengguna ilegal Obat Keras (seperti daftar "G" jenis Trihexyphenidil) dalam UU RI Nomor 36 Tahun 2009 Tentang Kesehatan telah berkonsekuensi terhadap pemberantasan Obat Keras yang tidak komprehensif. Ketentuan sanksi pidana yang hanya mengatur pada tahap produksi ilegal dan kepada para pengedar atau pun penjual ilegal, namun tidak sampai pada tatanan pembeli, Penyimpan, Pemilik dan/atau pengguna ilegal sehingga membuat penegakan hukum terhadap peredaran Obat Keras kurang berkepastian hukum dan kurang berkeadilan. Padahal pembeli, penyimpan, pemilik dan/atau pengguna yang telah nyata pembeli, penyimpan, pemilik dan/atau pengguna Obat Keras (seperti jenis Trihexyphenidil) tanpa menggunakan resep dokter telah memenuhi unsur sengaja yaitu menghendaki dan mengetahui, sehingga UU RI Nomor 36 Tahun 2009 tentang Kesehatan harus segera direvisi dengan memformulasi dan mengkriminalisasi pembeli aktif ilegal Obat Keras Daftar “G” jenis Trihexyphenidil dalam ketentuan pidana pada UU RI Nomor 36 Tahun 2009 tentang Kesehatan.

Dengan demikian sudah selayaknya pembeli, penyimpan, pemilik dan/ atau pengguna obat keras (seperti jenis Trihexyphenidil) diatur didalam undangundang tentang kesehatan mengingat obat keras (seperti jenis Trihexyphenidil) tidak kalah bahayanya dengan narkotika.

\section{Daftar Bacaan}

\section{Buku}

Andarisman T, Asas-Asas Dan Dasar Aturan Hukum Pidana Indonesia (Unila Bandar Lampung 2009).

Anwar Y\& A, Sistem Peradilan Pidana: Konsep, Komponen, E Pelaksanaannya Dalam Penegakan Hukum Di Indonesia (Widya Padjajaran 2011).

Dede Rosyada, Pendidikan Kewarganegaraan Demokrasi, HAM, Dan Masyarakat Madani (Puslit IAIN Syarif Hidayatullah 2000).

Harahap MY, Pembahasan Permasalahan Dan Penerapan KUHAP Pemeriksaan Sidang 
Pengadilan, Banding, Kasasi, Dan Peninjauan Kembali (Sinar Grafika 2008).

Lawrence M. Friedman, Sistem Hukum: Perspektif Ilmu Sosial (The Legal System: A Social Science Perspective (Nusa Media 2009).

Mertokusumo S, Mengenal Hukum (Liberty 1986).

Moeljatno, Asas Asas Hukum Pidana (Rineka Cipta 2002).

Muladi, Kapita Selekta Hukum Pidana (Badan Penerbit Universitas Diponegoro 1995).

Peter Mahmud Marzuki, Penelitian Hukum (Kencana Prenada Media Group 2008).

Roslan Saleh, Pelajaran Hukum Pidana I (Raja Grafindo Persada 2011).

Satjipto Raharjo, Masalah Penegakan Hukum Suatu Tinjauan Sosiologis (Sinar Baru 2005).

Sudarto, Kapita Selekta Hukum Pidana (Alumni 1986).

Tanya BL, Penegakan Hukum Dalam Terang Etika, Genta Publising, Yogyakarta, 2001,(Genta Publising 2001).

Wirjono Prodjodikoro, Asas-Asas Hukum Pidana Di Indonesia (Refika Aditama 2016).

\section{Laman}

Farmasi.com, 'Obat - Obat Daftar G' (artikelfarmasi.com, 2017) <http://www. artikelfarmasi.com/2017/05/obat-obat-daftar-g.html> accessed 18 February 2019.

Berita Acara Pemeriksaan Laboratoris Kriminalistik No.Lab: 9144/NOF/2018 tertanggal 05 Oktober 2018 pada Badan Reserse Kriminal Polri Pusat Laboratorium Forensik Cabang Surabaya.

How to cite: Moh. Heriyanto, Wahyu Hidayatullah, Mulyadi, 'Konsep Kriminalisasi Penegakan Hukum Terhadap Pembeli Aktif Ilegal Obat Keras Daftar “G” Jenis Trihexyphenidil' (2020) Vol. 3 No. 1 Media Iuris. 
--Halaman ini sengaja dibiarkan kosong-- 